\title{
Biotechnological

\section{Manipulating disease and pest resistance pathways in plants for enhanced crop improvement}

\author{
Paramita Ghosh, Anjanabha Bhattacharya* and Bharat Char \\ Maharashtra Hybrid Seeds Company Private Limited, Jalna-Aurangabad \\ Road, Dawalwadi, Jalna, Maharashtra, India
}

\begin{abstract}
Plants are sessile organisms, therefore cannot escape challenges of their surrounding environment. The rich source of nutrients plant possesses attracts various organisms. Biotic stress results from array of organisms such as bacteria, fungi to various insects, pests and herbivores. Plants have evolved sophisticated mechanisms to protect themselves against invaders. In this review, we explore the plant surveillance system, different nodes in the defence pathways involved in plant protection and how it can be manipulated to get a resistant crop. Emerging technologies have provided us with a vast number of potential candidate genes from plants, pathogens and other organisms. We here, illustrate examples of technically useful solutions to make crops tolerant to pathogens and pests.
\end{abstract}

KEY WORDS: PLANT DEFENCE, BIOTIC STRESS, R GENE, DEFENCE SIGNALING TRANSDUCTION, NPR1, MAPK, GENETIC ENGINEERING

\section{ABBREVIATIONS}

MAMPs - Microbe Associated Molecular Patterns,SAR Systemic Acquired Resistance, VOCS - Volatile Organic Compound, R gene - Resistance Gene, HR - Hypersensitive Reaction, ROS - Reactive Oxygen Species, MAPK - Mitogen Activated Protein Kinase, avr - Avirulence, ETI - Effector Triggered Immunity, NBS - Nuclear Binding Site, LRR - Leucine Rich Repeat, pv. - pathover, NO - Nitric Oxide, SA - Salicylic Acid, JA - Jasmonic Acid, ET- Ethylene, NPR1 - Non Expressor of PR Genes 1,PR - Pathogenesis Related, LTP -Lipid Transfer Pro-

\section{ARTICLE INFORMATION :}

*Corresponding Author: anjanabha.bhattacharya@mahyco.com Received $12^{\text {th }}$ Nov, 2017

Accepted after revision $29^{\text {th }}$ Dec, 2017

BBRC Print ISSN: 0974-6455

Online ISSN: 2321-4007 CODEN: USA BBRCBA

Thomson Reuters ISI ESC and Crossref Indexed Journal - NAAS Journal Score 2017: 4.31 Cosmos IF: 4.006 - A Society of Science and Nature Publication, 2017. All rights reserved.

Online Contents Available at: http//www.bbrc.in/

DOI: $10.21786 / \mathrm{bbrc} / 10.4 / 5$ tein, PPO - Polyphenol Oxidase, POD - Peroxidase, UV- Ultraviolet, HIPV - Herbivore Induced Plant Volatile, QTL - Qualitative Trait Loci, SIPK - Salicylic Acid Induced Protein Kinase, OS - Oral Secretion, FACs Fatty Acid -Amino Acid Conjugates, WIPK - Wound Induced Protein Kinase, MEKK- Mitogen-Activated Protein Kinase Kinase, ISR - Induced Systemic Resistance, PRSV - Papaya Ring Spot Virus, ZFN - Zinc Finger Nucleases, TALENs - TAL Effector Nucleases, GM - Genetically Modified, RPP2 - Recognition of peronospora parasitica 2 


\section{INTRODUCTION}

Plants are nutrient rich organisms and therefore many invaders prey on their food reserve. Some of the invaders are significant threats to crop production, worldwide. In the process of co-evolution (Seidl and Thomma, 2017); plants, pathogens and insects have evolved various strategies to avoid each others' defence system. The goal of producing crops with durable and increased resistance to a broad spectrum of diseases and insects is therefore, a major focus in plant research.

In nature, plants are continuously challenged by different organisms, whereas, only few are successful in gaining entry into a prospective host. Plants have developed an elegant defence system with a wide variety of constitutive and inducible defences to protect themselves from damages of different biotic factors. Constitutive defences include many preformed barriers such as waxy epidermal cuticles, cell walls and bark (specialized morphological structures). Inducible defences include production of repellents, toxic chemicals, pathogen-degrading enzymes, anti-nutritional effects and deliberate cell suicide (Freeman and Beattie, 2008). Plants often do not produce toxic compounds or defence-related proteins until pathogens are detected due to the metabolic cost associated with the production and maintenance of such compounds. Plants have evolved to live in environments where they are very often exposed to different stress factors in combination. Plants have developed various mechanisms that allow them to detect precise environmental changes and respond to complex stress conditions, minimizing damage (Saskia and Jorunn, 2011).

\section{NATURE OF ATTACKERS}

Plant pathogens can be broadly divided into biotrops and necrotrophs. Bacteria and fungi can adapt to both lifestyles (Freeman and Beattie, 2008).Viruses are quintessential biotrophs, although they eventually kill the host cell. Insects, on other hand, cause damage by chewing and sucking. Plants respond to the insects by producing protease inhibitors and anti-feedants such as alkaloids [(Hanley et al., 2007; Jeffery and Jonathan, 2001). Nematodes can adapt to complex modes of parasitism by exhibiting variety of parasitic modes affecting the development responses of plants, causing galls, root knots or cysts (Jeffery and Jonathan, 2001; Davis et al., 2004; Roland and Maurice,2011) . Thus, plant immune system is highly polymorphic in their capacity to recognize and respond to different stress factors (Jeffery and Jonathan, 2001).

\section{PLANT SURVEILLANCE SYSTEMS}

Although plants lack immune system comparable to animals, they have developed sophisticated surveillance mechanisms, which can respond rapidly before harmed. These surveillance systems are linked to specific preprogrammed defence responses. Direct defences are mechanical protection on the surface of the plants which protects from all biotic factors (e.g., hairs, trichomes, spines, thorns and thicker leaves) or toxic chemical production.

Basal resistance is the first line of pre-formed and inducible defences. It is also known as innate immunity (Freeman and Beattie, 2008; Owen and Zamir, 2010), and protect plants against entire groups of pathogens (Freeman and Beattie, 2008). Basal resistance is triggered when plants recognize microbe-associated molecular patterns (MAMPs). MAMPs include specific proteins, lipopolysaccharides, and components of cell wall commonly found in microbes. During evolution pathogens also have developed counter measures that are able to suppress basal resistance in certain plant species. If the basal defence is somehow suppressed, plants respond with hypersensitive response (HR) (Freeman and Beattie, 2008). In HR plants limit the pathogen's access to water and nutrients thereby sacrificing few cells in the infection site i.e. deliberate cell suicide (programmed cell death). HR is more pathogen specific than basal resistance. It is triggered in presence of disease-causing effector molecules. Once the hypersensitive response is triggered, plant tissues become highly resistant to a broad range of pathogens. This phenomenon is known as systemic acquired resistance (SAR) (Freeman and Beattie, 2008; Nelson et al., 2017), which represents readiness of plant metabolites to defend plants, in case of a heightened attack.

Mechanical damage caused by insects is not generally considered "true" plant disease although plants have developed surveillance systems designed to not only recognize insect pests, but also to respond with specific defence mechanisms. General wounding can be different from insect feeding in a way that elicitors are present in insect saliva. In response to insect chewing, plants release volatile organic compounds (VOCs), secondary metabolites and proteins that have toxic, repellent, and/or anti-nutritional effects on the herbivores (Freeman and Beattie, 2008; Saskia and Jorunn, 2011; Abdul Rashid War et al., 2012). Sometimes volatiles released by plants also attract beneficial predators (natural enemies) that prey on the destructive pests (Abdul Rashid War et al., 2012; Walling, 2000; Rashid and Chung, 2017). Plants become phenotypically plastic when induced defence is triggered as a result it decreases the chances of the attacking insects to adapt to the induced chemicals (Abdul Rashid War et al., 2012).

In addition, plants can defend themselves against viruses by a variety of mechanisms which include RNA silencing (Novina and Sharp, 2004, Csorba and Burgyan, 
2016). Plants can recognize the foreign double stranded RNA or DNA, produced by viruses in the host cell during replication, and respond by digesting the genetic strands into non recognizable fragments and thereby stopping the infection. The interaction of plants with symbionts, pathogen, herbivores, and the natural enemies, both above and below the ground is the focus of a large amount of research effort and has great potential for utilization in crop protection.

With cultivation of huge areas of genetically identical crops, protection relies on a small number of inbred disease resistance genes per crop species and on the wide-spread application of pesticides. Unfortunately, an absolute control is very difficult to achieve through pesticides (Cesari, 2017), as pathogens can overcome disease resistance genes and/or become resistant to pesticides (Nelson et al., 2017; Zhonghua et al., 2005). Genetic manipulation can help solve the problem by inserting multiple genes as transgenes by careful selection from wild parent of the same plant species or from different plant species (Campbell et al., 2002). Therefore a search is on for genes that can confer a durable broad-spectrum resistance against biotic factors. To make it more environment friendly the gene product should be safe for all organisms and also reduce the need of harmful pesticides. However, the success so far achieved is very less. In majority of cases the tansgene results in unpredictable expression in different parts of the plants, this phenomenon is not due to the transgene itself, per se (Hammond-Kosack and Parker, 2003; Stuiverand Custers, 2001) . Therefore, optimization of transgene expression patterns needs close attention. Inducible expression of such gene is essential (Hammond-Kosack and Parker, 2003; Michelmore, 2003). A highly inducible promoter specific for defence gene expression can help the plant in directed recourse allocation by metabolic and transcriptional adaption during stress. Plant can optimize source sink relationship thus increasing yield or biological harvest index (Hammond-Kosack and Parker, 2003).

\section{ENGINEERING PLANTS WITH INCREASED RESISTANCE AGAINST PATHOGEN AND INSECTS: TARGET GENES}

\section{(First generation strategies)}

\section{$R$ gene}

$\mathrm{R}$ genes (resistance genes) are important components of plant surveillance system. A diverse array of defence mechanism is triggered when $\mathrm{R}$ genes recognize pathogen or insects (Cesari, 2017). PR-gene induction, accumulation of inhibitory metabolites and oxidative burst response by production of reactive oxygen species, are some of the downstream responses triggered by $\mathrm{R}$ genes which lead to hypersensitive response (Owen and Zamir, 2010 ).

Pathogens possessing avr genes can overcome basal immunity of plants by blocking perception of PAMP or by inhibiting MAP kinase signaling cascade, which is known as effector- triggered susceptibility. In case of effector triggered immunity, the pathogen's effector molecules are recognized by $\mathrm{R}$ proteins either by direct or indirect interactions. Thus, enhancing the plant resistance and it is faster than PTI. To trigger ETI, R proteins must recognize specific avirulence proteins (Avr) in order to generate resistance. However, mutation in either avr gene or $\mathrm{R}$ gene can change the scene i.e it will result in compatibility and therefore loss of resistance. $R$ genes encode proteins which have nuclear binding sites (NBS) and leucine rich repeat (LRR) domains (NBS-LRR

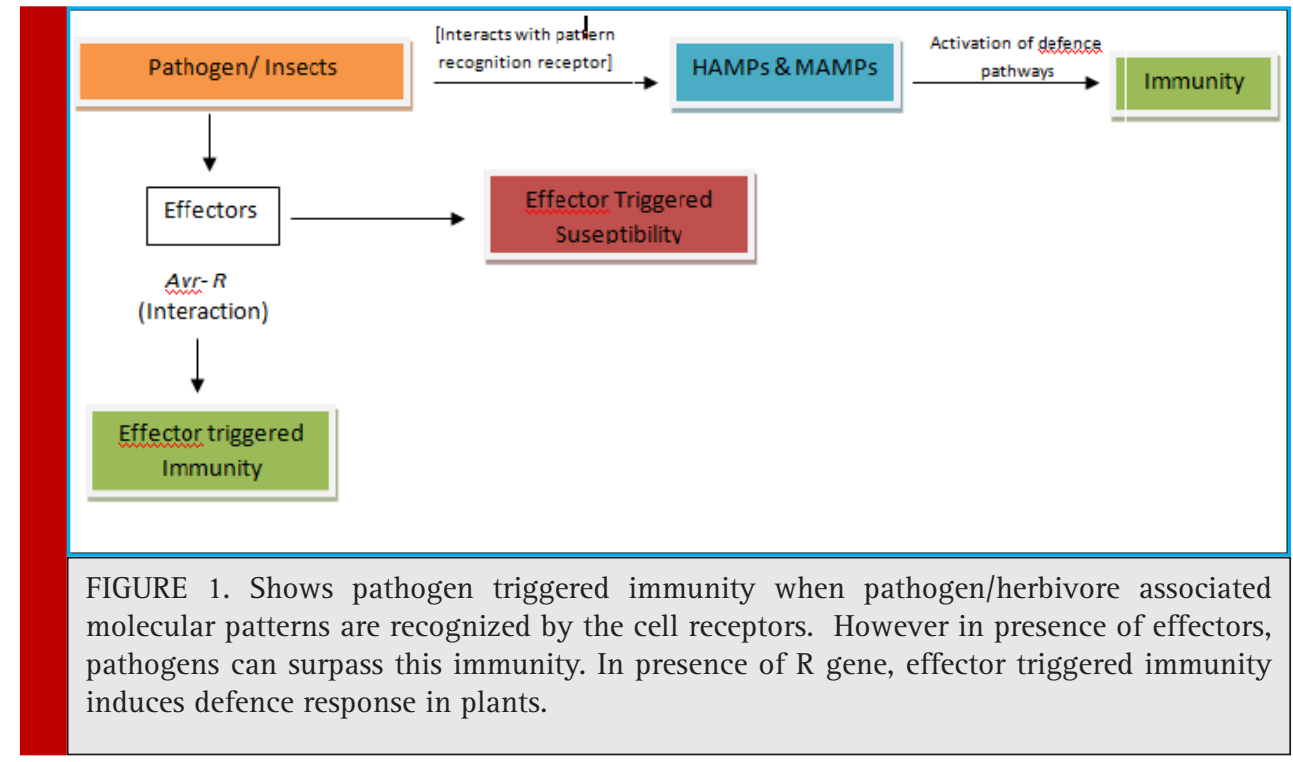


proteins) (Cesari, 2017; Jeffery and Jonathan, 2001; Mari et al.,2013, Nelson et al., 2017).

Functional $\mathrm{R}$ genes conferring resistance against an array of different biotic factors such as bacteria, virus, fungus, nematodes and even insect pathogens have been isolated (Cesari, 2017, Zhao et al., 2005; Vossen et al., 2005; Reinink et al., 1989; Brotman et al., 2002). Even though the mode of action as well as the effector molecules of pathogens and insects are very different, $\mathrm{R}$ genes encode only a few classes of proteins. NBS -LRR class of proteins are the largest class of $\mathrm{R}$ gene which encodes "nucleotide binding site with leucine rich repeat (Jeffery and Jonathan, 2001). It is reported that NB-LRR type $\mathrm{R}$ genes can confer resistance to multiple pathogens even though the pathogens belong to taxonomically distinct families (Mari et al., 2013). It is also termed as MDR or multiple disease resistance. In a maize recombinant inbred line (RIL) a QTL, $q M d r$ have been identified for resistance to several diseases i.e, Norther blight, grey leaf spot and souther leaf blight. The molecular mechanism underlying the resistance is yet not known. In a research it is found that a gene, ZmCCoAOMT2, which encodes a caffeoyl-CoA 0-methyltransferase is associated with conferring quantitative resistance to both southern leaf blight and gray leaf spot (Yang et al., 2017).

Bacterial effectors are delivered through type III secretion system, which can be up to 30 per strain, and by mimicking or inhibiting eukaryotic cellular functions colonization is achieved (Abramovitch et al. 2006). An example of a specific R-gene, Rxo 1 from maize conferred resistance to bacterial streak disease caused by Xanthomonas oryzae pv. Oryzicola(Zhao et al., 2005), when introduced in rice. In another instance, $\mathrm{R}$ gene RCT1 from Medicago truncatula expressed in alfalfa conferred resistance to Colletotrichum trifolii (Yang et al., 2008), RPI-BLB2 from wild potato gave resistance to Phytophtohora infestans in day to day cultivated potato (Vossen et al., 2005). Some of the R gene work in pairs and are functional only when both genes are present (Mari et al.,2013 ). Some of the examples of such $\mathrm{R}$ gene pairs are $R P P 2 A / R P P 2$ ( Sinapidou et al., 2004), Pi5-1/Pi5-2 ( Lee et al., 2009) and Lr10/RGA2 (Loutre et al., 2009). Examples in wheat rust, $\operatorname{Sr} 31$ from rye was effective against all $\mathrm{Pgt}$ races for many years until the appearance of Ug99 (Pretoriusetal.,2000).

Many single R genes responsible for resistance against insects are mapped in cereal crops, including wheat conferring resistance to Hessian fly (Hatchet et al., 1970). For decades, $\mathrm{R}$ genes have been used to control Hessian fly infestation in wheat. It is evident in support of genefor- gene model in plant- insect interactions.

Some of the insect resistant $\mathrm{R}$ genes that are effective against aphids include: the lettuce $N r$ gene which gives resistance against aphid species Nasanova ribis- nigri (Reinink et al., 1989), the Vat gene from melon confers resistance against the melon/cotton Aphis gossypii aphid (Brotman et al., 2002), in another instance, the $S d 1$ gene gives resistance against Dysaphis devecta aphid in apples (Walling, 2000; Roche et al. 1996), the $R A P 1$ gene gives resistance against the Pea Aphid in Medicago truncatula (Stewart et al., 2009), and the Mi-1 gene in tomatoes (Rossi et al., 1998) found to be responsible for resistance against different organisms, the potato aphid Macrosiphum euphorbiae, the root-knot nematodes Meloidogyne spp., and the whitefly Bemisia tabaci (Nombela et al. 2003). The diverse resistance conferred by the $M i-1$ gene makes it is a very useful tool for integrated pest management. While, Bph14 confers resistance to the rice brown planthopper, Nilaparvata lugens (Zhang et al., 2009). However, a constitutive expression of a $R$ gene can have a negative impact in absence of attackers. Constitutive expression of $\mathrm{R}$ gene can be detrimental to plants and therefore needs to be expressed with inducible promoters (Belbahri et al., 2001; Takakura et al., 2004).

For decades, $\mathrm{R}$ genes have been used in conventional breeding programme (Balconi et al., 2012) ; however, the resistance is only against a strain of pathogen or a particular species of insect. Traditional breeding strategies most often use only one $\mathrm{R}$ gene at a time. Pyramiding multiple $\mathrm{R}$ genes can promise a long lasting resistance as the pathogen has to accumulate mutation in multiple $A v r$ genes to escape resistance. Effective combinations of $\mathrm{R}$ and APR gene by pyramiding or stacking can be considered for effective rust resistance (Jeffrey et al., 2014). However, it is a lengthy process to introduce a $\mathrm{R}$ gene into an elite cultivar by conventional breeding. R-genes from unrelated plant species can be introduced through genetic engineering, which often remain functional in the new host plant (Collinge et al., 2008) . The limitation of this technology being that resistance is conferred only against a single pathogen similar to breeding (Balconi et al., 2012). Additionally, R-gene only confers resistance against pathogens that essentially act as a sink for the host plant's metabolism i.e. biotrophs.

Shuffling of multiple $\mathrm{R}$ genes can also be considered rather than only pyramiding. Plant pathogen Cladosporium fulvum elicitors are recognition by $C f$ genes in tomato which belongs to the Hcr9 gene clusters (Brande et al., 2004). Studies have shown that Hcr9s are composed of sequences that have been generated by sequence exchange between individual homologues, Intra and intergenic recombination, gene conversion, point mutation, duplication and translocation. Therefore, shuffling multiple $\mathrm{R}$ genes might increase recognition specificities and engineering $R$ gene for novel disease resistance specificities in plants can be achieved (Cesar, 2017). For example, gene shuffling done in tomato $C f 4$ and $C f 9 \mathrm{R}$ 


\begin{tabular}{|c|c|c|c|c|}
\hline $\mathrm{R}$ gene & Source (Donor) & $\begin{array}{l}\text { Examples of } \\
\text { transgenic crop }\end{array}$ & Against Pathogen & References \\
\hline $\operatorname{Rox} 1$ & Maize & Rice & Xanthomonas oryzae pv. oryzicola & Zhao et al., 2005 \\
\hline$R C T 1$ & Medicago truncatula & Alfalfa & Colletotrichum trifolii & Yang et al., 2008 \\
\hline$R P I-B L B 2$ & $\begin{array}{l}\text { Potato } \\
\text { (Solanum bulbocastanum) }\end{array}$ & Potato & Phytophtohora infestans & Vossen et al., 2005 \\
\hline Bs2 & Pepper & Tomato & Xanthomonas campestris & Tai et al., 1999 \\
\hline $\operatorname{Rpg} 1$ & Barley & Barley & Stem rust & Brueggeman et al., 2002 \\
\hline Vel and Ve2 & Tomato & Potato & Verticillium spp. & Kawchuk et al., 2001 \\
\hline$R R S 1-R$ & Arabidopsis & Arabidopsis & Ralstonia solanacearum & Deslandes et al., 2002 \\
\hline$P i-d 2$ & Rice & Rice & Chinese rice blast & Chen et al., 2006 \\
\hline$R P W 8$ & Arabidopsis & Arabidopsis, tobacco & $\begin{array}{l}\text { Broad spectum resistance against } \\
\text { powdery mildew }\end{array}$ & Xiao et al., 2003 \\
\hline Pto & Tomato & Tomato & Pseudomonas syringae & Frederick et al., 1998 \\
\hline
\end{tabular}

genes lead to the identification of sequences required for the Avr-dependent HR in tomato (Brande et al., 2001).

\section{SIGNAL TRANSDUCTION NETWORK}

Plants can sense changes in their environment through signaling pathways (Pankaj and Atle, 2013). When pathogen elicitors interact with host receptors, signal transduction cascades are likely to be activated including oxidative burst (ROS), calcium fluxes, ion channel fluxes, NO production (Bollwell et al., 1999) and various protein kinases. Subsequently, transcriptional and/ or post transcriptional activation of transcription factors takes place which lead to the induction of defence gene.

Plant hormones which play important role in defence are SA, JA and ET. SA is primarily involved in the protective response against biotrophic and hemi-biotrophic pathogens and systemic acquired resistance (SAR) (Grant and lamb, 2006). Some mutants insensitive to SA shows enhanced susceptibility to biotrophic pathogens. Methyl salicylate is a mobile inducer of SAR and is induced when the plant is infected with a pathogen in tobacco plants (Park et al., 2007). After pathogen challenge the elevated level of SA increases the expression of PR genes, therefore increasing resistance. Whereas the level of JA and ET are elevated against necrotrophic pathogen and herbivorous insects (Park et al., 2007).

Most often the SA and JA/ET defence pathways are antagonistic, however reports of synergistic interaction also exist (Kunkel and Brooks, 2002; Mur et al., 2006; Schenk et al., 2000) . Specific biotic factors regulate the positive or negative cross talk between SA and JA/ET pathways (Adie et al., 2007). In nature it is not one factor that affects the plant but several attackers, here plants have to employ complex regulatory mechanisms to cope with the complex situation. The mechanism by which plant is able to prioritize the responses is not known.

Non expressor of $P R$ genes 1 (NPR1) is one of the important components of SA signaling. NPR1 plays an important role in SA-JA interaction (Dong, 2004). Downstream of NPR1 are several WRKY transcription factors which is also important is SA-dependent defence response. WRKY70 maintains the balance between the SA and JA pathways (Li et al., 2004; Li et al., 2006). Another key component which is involved in mediating the antagonism between SA and JA signaling in Arabi-

\begin{tabular}{|l|l|l|l|}
\hline \multicolumn{6}{|l|}{ Table II. List of R gene against different insects } \\
\hline R gene & Source (Donor) & Against Insect & Reference \\
\hline Nr gene & lettuce & Aphid species Nasanova ribisnigri & Reinink et al., 1989 \\
\hline melon Vat gene & Melon & Melon/cotton Aphis gossypii aphid & Brotman et al., 2002 \\
\hline Sd1 gene & Apple & Dysaphis devecta aphid & Roche et al., 1996; Walling, 2000 \\
\hline RAP1 gene & Pea & Pea Aphid in Medicago truncatula & Stewart et al., 2009 \\
\hline Mi-1.2 gene & Tomato & $\begin{array}{l}\text { Potato aphid Macrosiphum euphorbiae, the } \\
\text { root-knot nematodes Meloidogyne spp., and } \\
\text { the whitefly Bemisia tabaci }\end{array}$ & Rossi et al., 1998 \\
\hline
\end{tabular}


dopsis is mitogen activated protein kinases (Petersen et al., 2000). In the second generation strategies, these signaling nodes will be discussed. The goal of effective and sustainable disease resistance can be achieved by the knowledge of signal transduction pathways (David et al., 2010), as the increased understanding has made it clear that successful pathogen process through pathogenicity factors (effectors). The disease resistance gene are mostly downstream genes and often do not act as specific receptors produced by pathogens and insects. A complex signaling network is also established when herbivorous insects attack a plant. To identify new molecules important for fine tuning of plant defence signaling, there is a need of dynamic modeling and simulation of signal transduction pathways (Beckers and Spoel, 2006; Erb et al., 2009).

Various plant protectant and defence gene are activated by the primary and secondary signals. The defence gene products include glutathione S-transferases, peroxidases, cell wall proteins, proteinase inhibitors, hydrolytic enzymes (e.g., $\beta$-1,3-glucanases and chitinases), pathogenesis-related PR proteins (Balconi et al., 2012).

\section{PR proteins}

Other potential candidates for manipulation are pathogenesis related (PR) genes, which shows promising activities against biotic factors i.e. pathogens as well as insect pests. Pathogenesis related (PR) genes could increase the level of pre-existing barriers (Owen and Zamir, 2010; Hammond-Kosack and Parker, 2003). Naturally occurring PR proteins are constitutively expressed at low levels and are induced to high levels challenged by pathogens or application of either salicylic acid or jasmonic acid (Ferreira et al., 2007) . PR proteins include several groups of unrelated proteins. Seventeen classes of PR protein have been examined, and numbered chronologically in order of discovery i.e. PR-1 to PR-17 (Balconi et al., 2012). PR-2 ( b -1,3-glucanases), PR-3, -4, -8 and -11 (chitinases) target the pathogen cell wall (Owen and Zamir, 2010; Honee, 1999), PR-1 and PR-5 (thaumatinlike proteins and osmotins) are termed as permatins as they target the membrane, PR-10 has weak ribonuclease activity therefore may target pathogen RNA or play a role in defence against viruses, PR-6 proteins (proteinase inhibitors) may target nematodes, whereas the PR-7 protein (an endoproteinase) may be involved in microbial cell wall dissolution (Jorda et al., 2000) . The PR-9 family may enhance resistance to multiple pathogens by catalyzing lignifications which helps in cell wall reinforcement (Passardi et al., 2004). Since PR-10 family has weak ribonuclease activity it can be used against viruses (Park et al., 2004), PR-12 (defensins), PR-13 (thionins) and PR-14 (lipid transfer proteins) predicts antibacterial and antifungal activities (Epple et al., 1997), some proteins generating hydrogen peroxide and are toxic to pathogen and pest, PR-15 (oxalate oxidases) and PR-16 (oxalate oxidase-like proteins) belongs to this family (Hu et al., 2003). PR-17 (uncharacterized) is detected in infected tobacco, wheat and barley (Christensen et al., 2002).

Most investigated PR proteins are chitinases and $\beta 1-3$ glucanases (Owen and Zamir, 2010). Over-expression of chitinase have been moderately successful against fungal pathogens. Studies have found chitinase have role in insect resistance as well. The combined expression of chitinases and $\beta 1-3$ glucanases have proven to enhance resistance by synergistic effect (Anand et al., 2003; Jach et al., 1995; Jongedijk et al., 1995; Zhu et al., 1994). Chitinases originating from Trichoderma harzianum (biocontrol agent), exhibit higher anti-fungal activity (Dana et al., 2006; Baranski et al., 2008; Kumar et al., 2009). Ectopic expression of thionins and defensins has conferred broad spectrum disease resistance, though the resistance is at low level (Punja, 2001). For example radish defensin RS-AFP2 (Kostov et al., 2009) when overexpressed in tomato resulted in up to $90 \%$ reduction in disease against agriculturally important pathogens. Lipid transfer proteins (LTP) are one of the important PR proteins which act as a potential mobile signal for systemic acquired resistance (SAR) in plants (Maldonado et al., 2002). LTP activates SAR over-expression of LTP might result in deleterious effect (Walters, 2007), so far no such effect is observed. A highly inducible promoter can be used to over-express this gene in order to achieve the goal of disease resistance.

The plant defensive metabolites are termed as secondary metabolites play an important role in plant defense against herbivore and other interspecies defense, thus increasing the fitness of the plant. They can be either constitutively stored (phytoanticipins) as inactive forms or induced in response to the insect or microbe attack (phytoalexins)(King et al., 2014). Herbivore induced plant volatiles (HIPVs) play very important role in defense by either attracting the natural enemies of the herbivores or by acting as feeding and/or oviposition deterrent (Rashid and Chung, 2017). HIPV are released by healthy plants as well, however a different blend of volatiles is produced in response to herbivory and is very specific for a particular insect-plant system (Liu et al., 2012). For example, plants tend to release volatile compounds in response to aphid -attack to attract parasitoid wasps. In corn, plants release terpenoids in response to aphid attack. Many other volatile compounds like MeSa, $\mathrm{C}_{6}$ volatiles etc influence plant-insect, pest and pathogen interaction.

Metabolite engineering can play an important role in developing plant with insect resistance. Increasing the flux of defence related secondary metabolites 
by engineering the respective pathways can be of great importance in developing crops with insect resistance (Sanchez -Vallet et al., 2013). There are some reports of metabolic engineering of dhurrin, a cyanogenic glycoside in transgenic $A$. thaliana plants which, resulted in minor effects on the whole metabolome and transcriptome (Dudareva et al., 2013 ). Resistance to green peach aphid (Myzus persicae) feeding have been enhanced by metabolic engineering of raffinose in the phloem of $A$. thaliana (Jirschitzka et al., 2013). In another instance, manipulation of plant volatile emissions has enhanced the effectiveness of biological control agents. This can be used as a strategy to fight insect pests in an ecologically sound manner (Degenhardt et al., 2009).

\section{SECOND GENERATION STRATEGIES}

\section{Master switch genes}

Over-expression of a single defence-related gene is generally unable to provide high levels of resistance against a broad range of biotic factors like pathogen and herbivores. The knowledge of pathogen-induced signaling pathways in plants suggests that modifications of existing innate signaling pathways or expression of 'masterswitch' genes such as kinases and transcription factors (Owen and Zamir, 2010; Hammond-Kosack and Parker, 2003; Sarah and Paul 2005), which regulate a large number of defence genes could increase resistance against biotic factors (Owen and Zamir, 2010; Sarah and Paul 2005). The disadvantage encountered by this approach could be the harmful effect on plant development, due to potential yield loss which is common with over-expression of large number of genes at a time constitutively (Owen and Zamir, 2010). Therefore, the ideal candidates are the genes that activate partial pathways or augment pathways.

\section{Transcription Factors}

Transcriptome and QTL data analysis suggested transcription factors to be promising candidates for genetic engineering to increase disease resistance characteristics in plants (Sarah and Paul 2005) . They might behave as master switch gene by taking care of the expression of several genes in a single pathway. Therefore capable of making large changes in single trait causing very few disturbance on other traits (Doebley and Lukens, 1998). A good example is WRKY transcription factors (Owen and Zamir, 2010; Sarah and Paul 2005).

WRKY transcription factors are involved in SA- mediated defence pathways. Several WRKYs have the potential for increasing disease resistance, among them the most studied are WRKY7O from Arabidopsis [50].Several other transcription factor families that have roles in plant defence could yield useful master switch genes like WRKY, ERF, TGA, MYB, Dof, GRAS, bHLH, GT1 and the Whirly factor Why1(Desvaux et al., 2004). The only limitation being, transcription factors mostly consist of large multigene families and identifying the best candidate can be difficult due to the functional redundancy (Eulgem et al., 2000). However, several of Arabidopsis WRKY has been identified have good functionality against pathogens (Sarah and Paul 2005).

\section{MAP Kinase}

Potential candidate master -switch genes which also play vital roles under different stress are protein kinases (Sarah and Paul 2005) . MAP kinase (MAPK) signaling is a necessary part of many defence-signalling pathways. When tobacco MAPK, SIPK is over-expressed it led to activation of defence responses and HR-like cell death showing the potential role of these genes (Zhang and Liu, 2001) . Enhanced resistance to virulent $P$. syringae and Botrytis cinerea was observed when MKK4a, MKK5a were over expressed transiently and MEKK1 was activated constitutively (Asai et al., 2002) . Other potential protein kinases are calcium dependent sensor proteins that changes $\mathrm{Ca}^{2+}$ defence response (Romeis et al., 2001) . In response to herbivore-induced cues such as insect oral secretions (OS) and oviposition fluid compounds, plants undergo a change in transcriptomes, proteomes, and metabolomes. The major components of the oral secretion of insects are fatty acid-amino acid conjugates (FACs) which activate the mitogen-activated protein kinase (MAPK) pathway. The MAPK pathway not only play an important role in signaling transduction in responses to a number of stresses including cold, heat, ROS, UV, drought, pathogen and insect attack but also regulate plant growth and development (Wu et al., 2007). On application of FACs in oral secretion of $M$. sexta leads to activation of several compounds/molecules of MAPKs, salicylic acid induced protein kinase (SIPK) and wound-induced protein kinase (WIPK), JA, SA and ethylene. In another case brown plant hopper $N$. lugens induces expression of putative OmMKKI (MAPK). Several FAC elicitors have been isolated from various lepidopteran species (Wu et al., 2007; von Dahl et al., 2007) .

\section{NPR1}

One of the most promising candidates of second generation strategy is NPR1 (Cao et al., 1994). Pathogen or insect pest resistance can be achieved through signaling modification. The Npr1 gene was discovered originally from various independent genetic screens. The Arabidopsis mutants npr-1 do not respond to inducers of systemic acquired resistance (SAR) such as salicylic acid (Cao et al., 1994; Delaney et al., 1995; Shah et al., 1997) 
or lost the ability to accumulate PR transcripts and were also hypersensitive to biotrophic pathogens (Pieterse et al., 2004). NPR 1 acts as a switch between the signaling pathways involving ethylene/jasmonic acid (ET/JA) (ISR) and salicylic pathway (SAR), therefore resistance to both necrotrophic and biotrophic pathogens depends on modulation of NPR1 gene (Li et al., 2004; Cao et al., 1994; Pieterse et al., 2004) . NPR1 is the key master switch as it constitutes a node which links SAR, ISR, SA, $\mathrm{JA}$, ethylene, and also R gene-mediated resistance (Pieterse et al., 2004). The activation of NPR 1 gene is through redox pathways by SA accumulation in the cytosol and then translocated to the nucleus, however without binding to DNA directly it acts through transcription factors, which in turn induces expression of several PR genes (Pieterse et al., 2004). NPR1 is constitutively expressed at low levels, when challenged by pathogen or treated with SA, transcript accumulation increases up to twofold. SA gives better defence against piercing and sucking insect pests than the chewing pests (Zhao et al., 2009).

SA-mediated expression of proteins by NPR 1 include the WRK70 transcription factors this lead to suppression of JA-dependent signaling events (Li et al., 2004; Ndamukong et al., 2007). However, nuclear localization of NPR 1 is not required for direct regulation of JA-path- ways which indicates a dual function between the cytosolic and nuclear located NPR1 (Glazebrook et al., 2003; Spoe et al., 2003; Yuan et al., 2007).

As both SA and JA dependant pathways are controlled by NPR1, it can be targeted to achieve broad spectrum disease resistance through genetic engineering. There are several instances where over-expression of NPR1 has resulted in resistance against both biotrophic (Cao et al., 1994; Lin et al., 2004). Necrotrophic (Lin et al., 2004; Makandar et al., 2006; Wally et al., 2009) pathogen in several plant species as well as against insect pest in tobacco plants. Over-expression of NPR1 resulted in quicker and higher intensity of PR proteins for longer duration. The function of NPR1 remained unchange when AtNPR 1 was expressed in different crop like rice (Fitzgerald et al., 2004), wheat (Makandar et al., 2006), carrot (Wally et al., 2009) tobacco ( Meur et al., 2008) and tomato (Lin et al., 2004) indicating the conserved functionality of the signaling system as well as the NPR1 like proteins.

However, when AtNPR1 or the rice ortholog 0sNH1 was expressed in transgenic rice, the constitutive expression of PR genes lead to stunted growth of plants and more light sensitivity apart from desired increase in disease resistance (Chern et al., 2005). Green tissue specific expression of AtNPR1 in rice reduced such developmen-

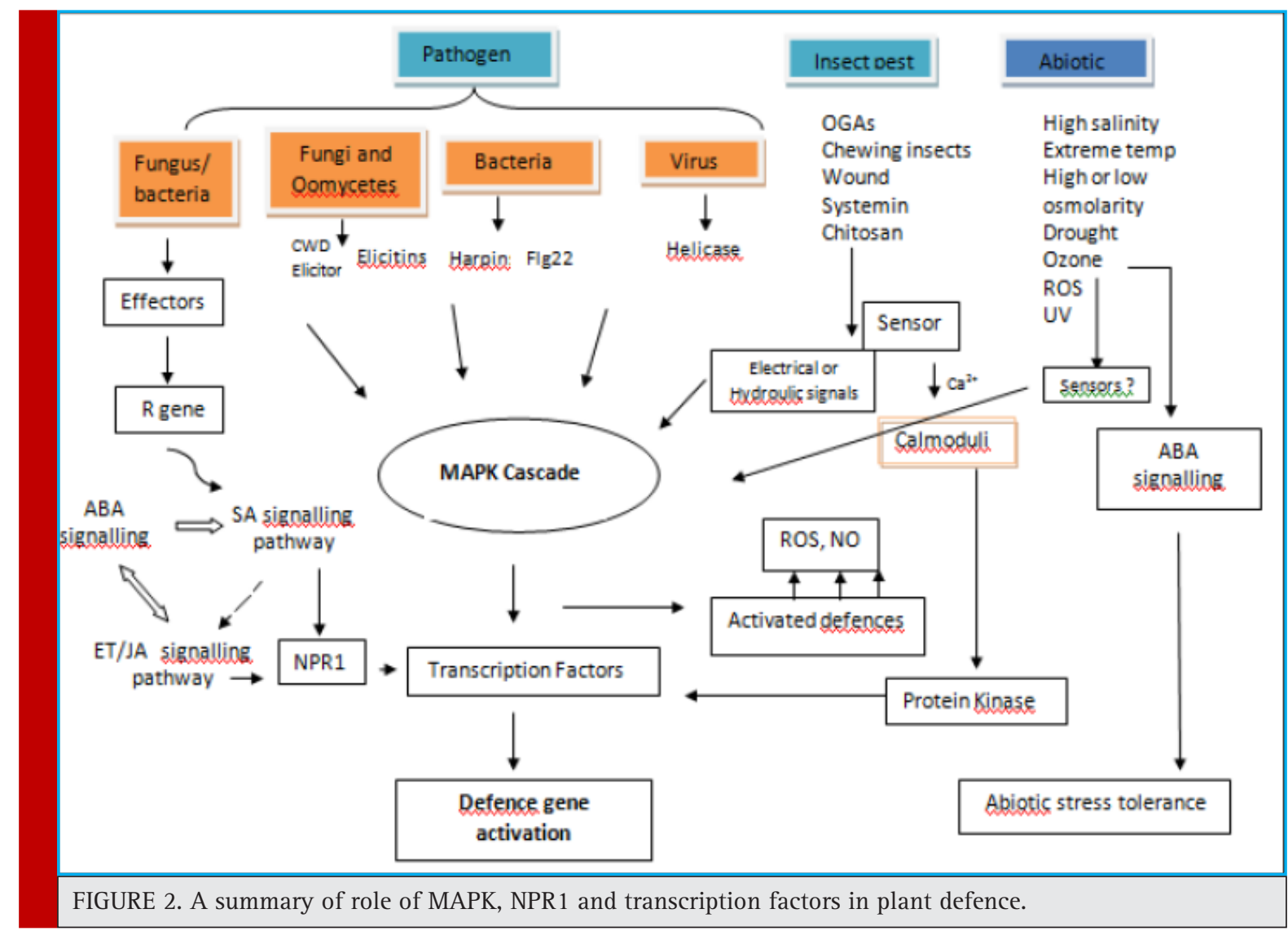


tal abnormalities and conferred resistance to the sheath blight pathogen without compromising the growth and yield parameters (Molla et al., 2016)

\section{MANIPULATION THE EXPRESSION OF TARGET GENES}

\section{Expressing Avr protein}

De Wit (1992) proposed an interesting exploitation of $\mathrm{R}$ gene response, where a plant can be designed to express an active Avr protein under the control of a pathogenresponsive promoter for which the plant has a $\mathrm{R}$ gene. The induced Avr product would induce responses which would result in incompatible reaction to a wide range of pathogens (Dewit, 1992). The pathogen inducible promoter (hsr203J) in tobacco resulted in successful exploitation of HR elicitor cryptogein (Keller et al., 1999). The main benefit is resistance against a wide range of pathogens. However the real value of this strategy is yet to be exploited.

\section{Synthetic modifications of PR proteins}

To enhance the effectiveness of PR proteins, synthetic modifications such as linking a single chain antibody gene against a particular pathogen can be done (Peschen et al., 2004). The antibodies would then attach to the invading pathogen's cell wall and the antimicrobial proteins would effectively degrade the fungi. It has been demonstrated against Fusarium graminearum. It was highly effective against nine different species of the Fusarium genus, in Arabidopsis, however, not effective against unrelated pathogens (Peschen et al., 2004). This method has been also implemented in transgenic wheat, which reduced the disease symptoms against Fusarium head blight (Li et al., 2008).

\section{Toxic gene products to engineer local cell death}

One of the first strategies applied for increased disease resistance in plants was generation of an 'HR-like' local cell death artificially by expressing a toxic gene (Li et al., 2008). This strategy is only successful when 'HR' is restricted to infection sites otherwise uncontrolled cell death will occur even in uninfected tissues which is undesirable. Components of the pathogen can be expressed as toxic genes. But the promoters used so far have undesired background expression in uninfected tissues. Moreover, the toxicity level of the gene product needs to be studied well before the product is marketed.

\section{RNAi}

A useful tool inhibiting pathogen expression is through RNAi (Csorba and Burgyan, 2016; Novina and Sharp, 2004) technology. It inhibits the expression at both the transcriptional and post transcriptional levels in plants.
RNAi has been exploited to develop many virus resistant plants (Fuentes et al.,2016). For example, papaya ringspot virus (PRSV) coat protein protected papaya in Hawaii has already been commercialized.

\section{Stacking antimicrobial compounds}

Expressing antimicrobial proteins, phytoalexins and enzymes in plant cell reinforcement or in the breakdown of pathogen infection structures has also been tried. The limitation of this strategy is resistance towards a specific pathogen. However to broaden the spectrum of resistance, stacking of antimicrobial peptides could be a reasonable approach (Van der Biezen, 2001).

\section{Targeting inducible promoters}

With the significant advances in sequencing technologies for transcriptome analysis, number of important crop genomes have been sequenced, which make it feasible for high throughput recognition of promoters and putative cis elements. Cis regulatory elements function as molecular switches in respose to various stress signals (Kazuko and Kazuo, 2005). Transcription factors interact with cis acting elements in the promoter region and forms a complex to initiate transcription thus can help in formation of initiation complex when activated and act as molecular switches to determine transcription initiation events. Therefore, it is important to determine the elements in the stress responsive promoters to understand the molecular switches of stress inducible genes. Apart from this, plant pathogen molecular interaction has shown that the promoter region also plays an important role in pathogen recognition (Patrick et al., 2009) . In gene for gene interaction pathogen effector interacts with the promoter region for activation of $\mathrm{R}$ gene. For example, some bacterial effectors like TAL effectors Avr BS3 and AVR Xa27 interact with the promoter region and activate the corresponding $\mathrm{R}$ genes (Patrick et al., 2009).

The current limitation of development of resistant transgenic crops using genetic transformation is unavailability of the right kind of promoter. Strong synthetic inducible promoters can be designed to address the issue of biotic stress. Promoters can be designed to not only recognize specific predators but also effector molecules from different pathogen and pests, thus giving a broad spectrum resistance against several biotic factors. It is also possible to use bidirectional promoters to activate two genes at the same time.

\section{CONCLUSION}

Durable pest and disease resistance so far has been achieved by traditional breeding and chemical applications. However, conventional breeding has prioritize 
quality parameters and agronomic adaptation over resistant breeding. Therefore, new improved genomic tools are required to empower the process of genetic analysis and crop improvement. High through put sequencing and complete genome sequencing of many crops allows understanding of many metabolic pathways and disease resistance mechanisms. Understanding of omics are shedding light on the different compounds associated with plant defense. Using new technologies, it might be possible to achieve more durable and long term resistance through various genetic approaches. The wide spread application of pesticides can also be reduced through this technology. There are several success stories of plant genetic engineering which include herbicide resistant for weed control and insect resistance for lepidopteran insect control. However, transgenic disease resistance crop and resistance against sap sucking insects represent a very small portion of transgenic crops. Also the scope is wide with the advancement of genome editing tools like CRISPR-Cas9 and new digital phenotyping technologies, to develop a more sustainable agriculture that involves adaptation to changing climates. The global food demand needs to be fulfilled and therefore, it is the need of the hour to combat yield losses caused by diseases and sap sucking insect pests on a global scale. Also, an increased and stable yield is required to address decreasing land availability issues. Engineering disease resistance with new tools available needs to be made a priority.

\section{REFERENCES}

Abdul Rashid War, Michael Gabriel Paulraj, Tariq Ahmad, Abdul Ahad Buhroo, Barkat Hussain, Savarimuthu Ignacimuthu, and Hari Chand Sharma (2012) Mechanisms of plant defence against insect herbivores. Plant signaling and Behavior 7:10, 1306-1320.

Abramovitch, R. B., Anderson, J. C., \&t Martin, G. B. (2006) Bacterial elicitation and evasion of plant innate immunity. Nature Reviews Molecular Cell Biology, 7(8):601-611.

Adie BA, Pérez-Pérez J, Pérez-Pérez MM, Godoy M, SánchezSerrano JJ, Schmelz EA, Solano R. (2007) ABA is an essential signal plant resistance to pathogens affecting JA biosynthesis and the activation of defence in Arabidopsis. Plant Cell 19:1665-1681.

Anand A, Zhou T, Trick HN, Gill BS, Bockus WW, Muthukrishnan S. (2003) Greenhouse and field testing of transgenic wheat plants stably expressing genes for thaumatin-like protein, chitinase and glucanase against Fusarium graminearum. Nature Reviews Molecular Cell Biology 54:1101-11.

Asai T, Tena G, Plotnikova J, Willmann MR, Chiu WL, GomezGomez L, Boller T, Ausubel FM, Sheen J. (2002) MAP kinase signalling cascade in Arabidopsis innate immunity. Nature 415:977-983.
Baranski R, Klocke E, Nothnagel T. (2008) Chitinase CHIT36 from Trichoderma harzianum enhances resistance of transgenic carrot to fungal pathogens. Journal of Phytopathology 2008; 156:513-21.

Beckers GJM, Spoel SH. (2006) Fine-tuning plant defence signalling: salicylate versus jasmonate. Plant Biology 8:1-10.

Belbahri L, Boucher C, Candresse T, Nicole M, Ricci P, Keller H. (2001) A local accumulation of the Ralstonia solanacearum PopA protein in transgenic tobacco renders a compatible plant-pathogen interaction incompatible. The Plant Journal 28:419-30.

Bollwell, G.P. (1999) Role of active oxygen species and NO in plant defence. Current Opinion in Plant Biology 2:287-294.

Brande B.H. Wulff, Marco Kruijt, Peter L. Collins, Colwyn M. Thomas, Andrea A. Ludwig, Pierre J.G.M. De Wit and Jonathan D.G. Jones (2004) Gene shuffling-generated and natural variants of the tomato resistance gene Cf- 9 exhibit different autonecrosis-inducing activities in Nicotiana species. The Plant Journal 40: 942-956.

Brande B. H. Wulff, Colwyn M. Thomas, Matthew Smoker, Murray Grant,and Jonathan D. G. Jones (2001) Domain Swapping and Gene Shuffling Identify Sequences Required for Induction of an Avr-Dependent Hypersensitive Response by the Tomato Cf-4 and Cf-9 Proteins. The Plant Cell 13:255-272.

Brotman Y, Silberstein L, Kovalski I, Périnin C, Dogimont C, Pitrat M, ,Klingler J, Thompson A, Perl-Treves R. (2002) Resistance gene homologues in melon are linked to genetic loci conferring disease and pest resistance. Theoretical and Applied Genetics_104(6-7):1055-1063.

Campbell, M.A. Matthew A. Campbell, Heather A. Fitzgerald, Pamela C. Ronald. (2002) Engineering pathogen resistance in crop plants. Transgenic Research 11:599-613.

Cao H, Bowling SA, Gordon AS, Dong XN. (1994) Characterization of an Arabidopsis mutant that is nonresponsive to inducers of systemic acquired-resistance. Plant Cell 6:1583-92.

Carlotta Balconi , Piergiorgio Stevanato , Mario Motto and Enrico Biancardi. (2012) Breeding for biotic stress resistance / tolerance in plants. Crop Production for Agricultural Improvement pp 57-114.

Cesari S. (2017) Multiple strategies for pathogen perception by plant immune receptors. New Phytologist nph.14877

Chern M, Fitzgerald HA, Canlas PE, Navarre DA, Ronald PC. (2005) Overexpression of a rice NPR1 homolog leads to constitutive activation of defence response and hypersensitivity to light. Molecular Plant-Microbe Interactions 18:511-20.

Christensen A, Ho Cho B, Naesby M, Gregersen PL, Brandt $\mathrm{J}$, Madriz-Ordeñana $\mathrm{K}$, Collinge DB, Thordal-Christenen $\mathrm{H}$. (2002) The molecular characterization of two barley proteins establishes the novel PR-17 family of pathogenesis-related proteins. Molecular Plant Pathology 3:135-144.

Collinge DB, Lund OS, Thordal-Christensen H. (2008) What are the prospects for genetically engineered, disease resistant plants? European Journal of Plant Pathology 121:217-31. 
Csorba T. and Burgyan J, (2016) Antiviral Silencing and Suppression of Gene Silencing in Plants. Springer International Publishing Switzerland.

Dana MD, Pintor-Toro JA, Cubero B. (2006) Transgenic tobacco plants overexpressing chitinases of fungal origin show enhanced resistance to biotic and abiotic stress agents. Plant Physiology 142:722-30.

David B. Collinge, Hans J.L. Jørgensen, Ole S. Lund, and Michael F. Lyngkjær (2010) Engineering Pathogen Resistance in Crop Plants: Current Trends and Future Prospects. Annual Review of Phytopathology 48:269-91.

Davis EL, Hussey RS, Baum TJ (2004) Getting to the roots of parasitism by nematodes. Trends in Parasitology 20(3):134-41.

Degenhardt J, Hiltpold I, Kollner TG, Frey M, Gierl A, Gershenzon J, Hibba BE, Ellersieck MR, Turlings TCJ. (2009) Restoring a maize root signal that attracts insect-killing nematodes to control a major pest. Proceedings of the National Academy of Sciences, USA 106:13213-13218.

Delaney TP, Friedrich L, Ryals JA. (1995) Arabidopsis signaltransduction mutant defective in chemically and biologically induced disease resistance. Proceedings of the National Academy of Sciences USA 92:6602-6606.

Desveaux D, Subramaniam R, Després C, Mess JN, Lévesque C, Fobert PR, Dangl JL, Brisson N. (2004) A "Whirly" transcription factor is required for salicylic acid-dependent disease resistance in Arabidopsis. Developmental Cell 6(2):229240.

Doebley J. and Lukens L (1998) Transcriptional regulators and the evolution of plant form. Plant Cell 10:1075-1082.

De Wit PJGM. (1992) Molecular characterization of gene-forgene systems in plant-fungus interactions and the application of avirulence genes in control of plant-pathogens. Annual Review of Phytopathology 30:391-418.

Dong X. (2004) NPR1, all things considered. Current Opinion in Plant Biology 7:547-552.

Du B, Zhang W, Liu B, Hu J, Wei Z, He R, Zhu L, Chen R, Han B and He G. (2009) Identification and characterization of Bph14, a gene conferring resistance to brown planthopper in rice. Proceedings of the National Academy of Sciences USA, 106:22163-22168.

Dudareva N, Klempien A, Muhlemann JK, Kaplan I. (2013) Biosynthesis, function and metabolic engineering of plant volatile organic compounds. New Phytologist 198:16-32.

Epple P, Apel K, Bohlamann H. (1997) Overexpression of an endogenous thionin enhances resitance of Arabidopsis against Fusarium oxysporum . Plant Cell 9:509-520.

Erb M, Flors V, Karlen D, de Lange E, Planchamp C, D’Alessandro M, Turlings TCJ, Ton J. (2009) Signal signature of aboveground-induced resistance upon belowground herbivory in maize. The Plant Journal 59:292-302.

Eulgem, T.E, Rushton PJ, Robatzek S, Somssich IE. (2000) The WRKY superfamily of plant transcription factors. Trends Plant Science 5:199-206.
Ferreira RB, Monteiro S, Freitas R, Santos CN, Chen Z, Batista LM, Duarte J, Borges A, Teixeira AR. (2007) The role of plant defence proteins in fungal pathogenesis. Molecular Plant Pathology 8:677-700.

Fitzgerald HA, Chern MS, Navarre R, Ronald PC. (2004) Overexpression of (At)NPR1 in rice leads to a BTH-and environment-induced lesion-mimic/cell death phenotype. Molecular Plant-Microbe Interactions 17:140-51.

Freeman and G.A Beattie. (2008) An overview of plant defences against pathogen and herbivores. The Plant Health Instructor. DOI:10.1094/PHI-I-2008-0226-01.

Fuentes A, Carlos N, Ruiz Y, Callard D, Sánchez Y, Ochagavía ME, Seguin J, Malpica-López N, Hohn T, Lecca MR, Pérez R, Doreste V,Rehrauer H, Farinelli L, Pujol M, Pooggin MM (2016) Field Trial and Molecular Characterization of RNAiTransgenic Tomato Plants That ExhibitResistance to Tomato Yellow Leaf Curl Geminivirus. Mol Plant Microbe Interact 29(3):197-209.

Glazebrook J, Chen WJ, Estes B, Chang HS, Nawrath C, Metraux JP, Zhu T, Katagiri F. (2003) Topology of the network integrating salicylate and jasmonate signal transduction derived from global expression phenotyping. Plant Journal 34:217-28.

Grant M and Lamb C (2006) Systemic immunity. Current Opinion in Plant Biology 9:414-420.

Hammond-Kosack, K.E. and Parker, J.E. (2003) Deciphering plantpathogen communication: fresh perspectives for molecular resistance breeding. Current Opinion in Biotechnology 14:177-193.

Hanley ME, Lamont BB, Fairbanks MM, Rafferty CM. (2007) Plant structural traits and their role in antiherbivore defence. Perspec. Plant Ecol Evol Syst 8:157-78.

29. Hatchet JH, Gallun RL (1970) Genetics of ability of Hessian fly, Mayetiola-Destructor Diptera -Cecidomyiidae to survive on wheats having genes for resiatnce. Annals of the Entomological Society of America 63:1400-1407.

Honee G (1999) Engineered resistance against fungal plant pathogens. European Journal of Plant Pathology 105:319-326.

Hu X, Bidney DL, Yalpani N, Duvick JP, Crasta O, Folkerts O, Lu G. (2003) Over expression of a gene encoding hydrogen peroxide-generating oxalate oxidase evokes defence responses in sun fl ower. Plant Physiology 133:170-181.

http://www.nap.edu/read/2116/chapter/5

Jach G, Gornhardt B, Mundy J, Logemann J, Pinsdorf E, Leah R, Schel J, Maas C. (1995) Enhanced quantitative resistance against fungal disease by combinatorial expression of different barley antifungal proteins in transgenic tobacco. The Plant Journnal 1995; 8:97-109.

.Jeffrey G. Ellis, Evans S. Lagudah, Wolfgang Spielmeyer and Peter N. Dodds (2014) Thepast,presentandfutureofbreedingrustr esistantwheat. Frontiers in plant science vol5, article 641.

Jeffery L. DangI and Jonathan D.G. Jones (2001) Plant pathogens and integrated defence responses to infection. Nature Vol 411. 
Jirschitzka J, Mattern DJ, Gershenzon J, D’Auria JC. (2013) Learning from nature: new approaches to the metabolic engineering of plant defense pathways. Current Opinion in Biotechnology 24, 320-328.

Jongedijk E, Tigelaar H, Vanroekel JSC, Bresvloemans SA, Dekker I, Vandenelzen PJM, Cornelissen BJC, Melchers LS. (1995) Synergistic activity of chitinases and beta-1,3-Glucanases enhances fungal resistance in transgenic tomato plants. Euphytica 85:173-80.

Jordá L, Conejero V, Vera P (2000) Characterization of P69E and P69F , two differentially regulated genes encoding new members of the subtilisin-like proteinasi family from tomato plants. Plant Physiology 122:67-74.

Kazuko Yamaguchi-Shinozaki and Kazuo Shinozaki (2005) Organization of cis-acting regulatory elemens in osmotic and cold -stress-responsive promoters. Trends in plant science. Vol. 10 No.2.

Keller H, Pamboukdjian N, Ponchet M, Poupet A, Delon R, Verrier JL, et al. (1999) Pathogen-induced elicitin production in transgenic tobacco generates a hypersensitive response and nonspecific disease resistance. Plant Cell 11:223-35.

King SRF, McLellan H, Boevink BC, Armstrong MR, Bukharova T, Sukarta O, Win J, Kamoun S, Birch PRJ, Banfield MJ. (2014) Phytophtora infestans RXLR effector PexRD2 interacts with host MAPKKKe to suppress plant immune signaling. Plant Cell.113.120055.

Kostov K, Christova P, Slavov S, Batchvarova R. (2009) Constitutive expression of a radish defensin gene Rs-Afp2 in tomato increases the resisstance to fungal pathogens. Biotechnology $\mathrm{Ct}$ Biotechnological Equipment 23:1121-5.

Kumar V, Parkhi V, Kenerley CM, Rathore KS. (2009) Defencerelated gene expression and enzyme activities in transgenic cotton plants expressing an endochitinase gene from Trichoderma virens in response to interaction with Rhizoctonia solani. Planta 230:277-91.

Kunkel BN, Brooks DM. (2002) Cross talk between signaling pathways in pathogen defence. Current Opinion in Plant Biology 5:325-331.

Lee SK, song MY, Seo YS, Kim HK, Ko S, et al.(2009) Rice Pi5mediated resistance to Magnaporthe oryzae requires the presence of two CC-NBLRR genes. Genetics 181:1627-1638.

Li HP, Zhang JB, Shi RP, Huang T, Fischer R, Liao YC. (2008) Engineering fusarium head blight resistance in wheat by expression of a fusion protein containing a fusarium-specific antibody and an antifungal peptide. Molecular Plant-Microbe Interactions 2008; 21:1242-8.

Li J, Brader G, Palva ET. (2004) The WRKY70 transcription factor: A node of convergence for jasmonate-mediated and salicylate-mediated signals in plant defence. Plant Cell 16:319-31.

Li J, Brader G, Kariola T, Palva ET (2006) WRKY70 modulates the selection of signaling pathways in plant defence. The Plant Journal 46:477-491.

Lin WC, Lu CF, Wu JW, Cheng ML, Lin YM, Yang NS, Black L, Green SK, Wang JF, Cheng CP. (2004) Transgenic tomato plants expressing the Arabidopsis NPR1 gene display enhanced resistance to a spectrum of fungal and bacterial diseases. Transgenic Research 13:567-81.

Liu T, Liu Z, Song C, Hu Y, Han Z, She J, Fan F, Wang J, Jin C, Chang J, Zhou JM, Chai J. (2012) Chitin-induced dimerization activates a plant immune receptor. Science 336:1160-1164.

Loutre C, Wicker T, Travella S, Galli P, Scofield S, et al. (2009) Two different CC-NBS-LRR genes are required for Lr10 -mediated leaf rust resistance in tetraploid and hexaploid wheat. Plant Journal 60: 1043-1054.

Magdalena Rossi, Fiona L. Goggin, Stephen B. Milligan, Isgouhi Kaloshian, Diane E. Ullman, and Valerie M. Williamson (1998) The nematode resistance gene Mi of tomato confers resistance against the potato aphid. Proceedings of the National Academy of Sciences USA 95:9750-9754.

Makandar R, Essig JS, Schapaugh MA, Trick HN, Shah J. (2006) Genetically engineered resistance to Fusarium head blight in wheat by expression of Arabidopsis NPR1. Molecular PlantMicrobe Interactions 19:123-9.

Maldonado AM, Doerner P, Dixon RA, Lamb CJ, Cameron RK. (2002) A putative lipid transfer protein involved in systemic resistance signaling in Arabidopsis. Nature 419:399-403.

Mari Narusaka, Kubo Y, Hatakeyama K, Imamura J, Ezura H, Nanasato Y, Tabei Y, Takano Y, Shirasu K , Narusaka Y. (2013) Interfamily Transfer of Dual NB-LRR Genes Confers Resistance to multiple pathogens. . Public Library of Science (PLOS) one 8:e55954.

Meur G, Budatha M, Srinivasan T, Kumar KRR, Gupta AD, Kirti PB. (2008) Constitutive expression of Arabidopsis NPR1 confers enhanced resistance to the early instars of Spodoptera litura in transgenic tobacco. Physiologia Plantarum 133:76575.

Michelmore, R.W. (2003) The impact zone: genomics and breeding for durable disease resistance. Current Opinion in Plant Biology 6:397-404.

Molla KA, Karmakar S, Chanda PK, Sarkar SN, Datta SK, Datta K (2016). Tissue-specific expression of Arabidopsis NPR1 gene in rice for sheath blight resistance without compromising phenotypic cost. Plant Sci 250:105-114.

Mur LA, Kenton P, Atzorn R, Miersch 0 and Wasternack C. (2006) The outcomes of concentration include synergy, antagonism, and oxidative stress leading to cell death. Plant Physiology 140:249-262.

Ndamukong I, Al Abdallat A, Thurow C, Fode B, Zander M, Weigel R, Gatz C. (2007) SA-inducible Arabidopsis glutaredoxin interacts with TGA factors and suppresses JA-responsive PDF1.2 transcription. The Plant Journal 50:128-39.

Nelson R, Wiesner-HanksT, Wisser R and Balint-Kurti P (2017) Navigating complexity to breed disease-resistant crops. Nature Reviews Genetics (Advanced publication)

Nombela, G., Williamson, V. M., \& Muñiz, M. (2003). The rootknot nematode resistance gene Mi-1.2 of tomato is responsible for resistance against the whitefly Bemisia tabaci. Molecular Plant-Microbe Interactions 16(7):645-649. 
Novina, C.D. and Sharp, P.A. (2004) The RNAi revolution. Nature 430:161-164.

Pankaj Barah and Atle M. Bones (2013) Controlling crop diseases using induced resistance:challenges for the future. Journal of Experimental Botany 64:1263-1280.

Park CJ, Kim KJ, Shin R, Park JM, Shin YC, Paek KH (2004) Pathogenesis-related protein 10 isolated from hot pepper functions as a ribonuclease and an antiviral pathway. The Plant Journal 37:186-198.

Park SW, Kaimoyo E, Kumar D, Mosher S, Klessig DF. (2007) Methyl salicylate is a critical mobile signal for plant systemic acquired resistance. Science 318:113-116

Passardi F, Penel C, Dunand C (2004) Performing the paradoxical- How plant peroxidases modify the cell wall. Trends in Plant Science 9:534-540.

Patrick Romer, Sabine Recht, and Thomas Lahaye (2009) A single plant resistance gene promoter engineered to recognize multiple TAL effectors from disparate pathogens. Proceedings of the National Academy of Sciences vol. 106, no. 48.

Peschen D, Li HP, Fischer R, Kreuzaler F, Liao YC. (2004) Fusion proteins comprising a Fusarium-specific antibody linked to antifungal peptides protect plants against a fungal pathogen. Nature Biotechnology 22:732-8.

Petersen M, Brodersen P, Naested H, Andreasson E, Lindhart U, Johansen B,Nielsen HB,Lacy M, Austin MJ, Parker JE, Sharma SB, Klessig DF, Martienssen R, Mattsson O, Jensen AB, Mundy J. (2000) Arabidopsis map kinase 4 negetively regulates syatemic acquired resistance. Cell 103:11111120.

Pieterse CM, Van Loon L. (2004) NPR1: the spider in the web of induced resistance signaling pathways. Current Opinion in Plant Biology7:456-64.

Pretorius,Z.,Singh,R.,Wagoire,W.,andPayne,T.(2000).Detection of virulence to wheat stem rust resistance gene Sr31in Pucciniagraminis. f. sp. tritici in Uganda. PlantDis. 84:203203.

Punja ZK. (2001) Genetic engineering of plants to enhance resistance to fungal pathogens-a review of progress and future prospects. Canadian Journal of Plant Pathology 23:216-35.

Rashid MH, and Chung YR (2017) Induction of Systemic Resistance against Insect Herbivores in Plants by Beneficial Soil Microbes. Frontiers in Plants Science 08:1816.

Roche PA, Alston FH, Maliepaard CA, Evans KM, Vrielink R, Dunemann F, Markussen T, Tartarini S, Brown LM, Ryder C, King GJ. (1996) RFLP and RAPD markers linked to the rosy leaf curling aphid resistance gene (Sd1) in apple. Theoretical and Applied Genetics 94:528e33.

Reinink K, Dieleman FL. (1989) Comparison of sources of resistance to leaf aphids in lettuce (L. sativa L.). Euphytica 40:21-29.

Roland N. Perry , Maurice Moens (2011) Introduction to PlantParasitic Nematodes; Modes of Parasitism. Chapter Genomics and Molecular Genetics of Plant-Nematode Interactions pp 3-20Date: 27.
Romeis, T, Ludwig AA, Martin R, Jones JDG. (2001) Calciumdependent protein kinases play an essential role in a plant defence response. The EMBO Journal 20:5556-5567.

Sanchez-Vallet A, Saleem-Batcha R, Kombrink A, Hansen G, Valkenburg DJ, Thomma BPHJ, Mesters JR (2013) Fungal effector Ecp6 outcompetes host immune receptor for chitin binding through intrachain LysM dimerization. eLife 2: e00790.

Saskia A Hogenhout and Jorunn IB Bos. (2011) Effector proteins that modulate plant - insect interactions. Current Opinion in Plant Biology 14:422-428.

Schenk PM, Kazan K, Wilson I, Anderson JP, Richmond T, Somerville SC, and Manners JM (2000) Coordinated plant defence responses in Arabidopsis revealed by microarray analysis. Proceedings of the National Academy of Sciences USA 97:11655-11660

Sarah J. Gurr and Paul J. Rushton (2005). Engineering plants with increased disease resistance: what are we going to express? Trends in Biotechnology 23: 275-282.

Shah J, Tsui F, Klessig DF (1997) Characterization of a salicylic acid-insensitive mutant (sai1) of Arabidopsis thaliana, identified in a selective screen utilizing the SA-inducible expression of the tms 2 gene. Molecular Plant-Microbe Interactions 10:69-78.

Seidl MF and Thomma BPHJ. (2017) Transposable Elements Direct The Coevolution between Plants and Microbes. Trends Genet 33(11):842-851

Spoe et al., 2003; Spoel SH, Koornneef A, Claessens SMC, Korzelius JP, Van Pelt JA, Mueller MJ, Buchala A J, Métraux J P, Brown R, Kazan K, Van Loon LC, Dong X and Pietersea CMJ. (2003) NPR1 modulates cross-talk between salicylate- and jasmonate-dependent defence pathways through a novel function in the cytosol. The Plant Cell 15:760-70.

Stuiver, M.H. and Custers, J.H.H.V. (2001) Engineering disease resistance in plants. Nature 411:865-868.

Sinapidou E, Williums K, Nott L, Bahkt S, Tor M, Crute I, Bittner-Eddy P and Beynon J. (2004) Two TIR:NB:LRR genes are required to specify resistance to Peronospora parasitica isolate Cala2 in Arabidopsis. The Plant Journal 38:898-909.

Stewart, S. A., Hodge, S., Ismail, N., Mansfield, J. W., Feys, B. J., Prospéri, J. M. \&t Powell, G. (2009). The RAP1 gene confers effective, race-specific resistance to the pea aphid in Medicago truncatula independent of the hypersensitive reaction. Molecular plant-microbe interactions 22(12):1645-1655.

Takakura Y, Ishida Y, Inoue Y, Tsutsumi F, Kuwata S. (2004) Induction of a hypersensitive response-like reaction by powdery mildew in transgenic tobacco expressing harpin(pss). Physiological and Molecular Plant Pathology 64:83-9.

van der Biezen, E.A. (2001) Quest for antimicrobial genes to engineer disease-resistant crops. Trends in Plant Science 6:8991.

van der Vossen EA, Gros J, Sikkema A, Muskens M, Wouters D, Wolters P, Pereira A, Allefs S. (2005) The Rpi-blb2 gene from Solanum bulbocastanum is an Mi-1 gene homolog confer- 
ring broad-spectrum late blight resistance in potato. The Plant Journal 44:208-22.

von Dahl CC, Winz RA, Halitschke R, Kühnemann F, Gase K, Baldwin IT. (2007) Tuning the herbivore-induced ethylene burst: the role of transcript accumulation and ethylene perception in Nicotiana attenuata. The Plant Journal 51:293-307.

Wally 0 and Punja ZK. (2010) Genetic engineering for increasing fungal and bacterial disease resistance in crop plants. GM Crops 1:4,199-206.

Wally 0, Jayaraj J, Punja ZK (2009) Broad-spectrum disease resistance to necrotrophic and biotrophic pathogens in transgenic carrots (Daucus carota L.) expressing an Arabidopsis NPR1 gene. Planta 231:131-41.

Walling LL. (2000) The myriad plant responses to herbivores. Journal of Plant Growth Regulation 19:195-216; PMID:11038228.

Walters D, Heil M. (2007) Costs and trade-offs associated with induced resistance. Physiological and Molecular Plant Pathology 71:3-17.

Wu JQ, Hettenhausen C, Meldau S, Baldwin IT. (2007) Herbivory rapidly activates MAPK signaling in attacked and unattacked leaf regions but not between leaves of Nicotiana attenuata. Plant Cell 19:1096- 122.

Yang Q., He Y., Kabahuma M. et al., (2017) A gene encoding maize caffeoyl-CoA $O$-methyltransferase confers quantitative resistance to multiple pathogens. Nature Genetics 49:1364-1372.

Yang SM, Gao MQ, Xu CW, Gao JC, Deshpande S, Lin SP, et al. (2008) Alfalfa benefits from Medicago truncatula: The RCT1 gene from M. truncatula confers broad-spectrum resistance to anthracnose in alfalfa. Proceedings of the National Academy of Sciences USA 105:12164-9.

Yuan Y, Zhong S, Li Q, Zhu Z, Lou Y, Wang L, Wang J, Wang M, Li Q, Yang D, He Z. (2007) Functional analysis of rice NPR1like genes reveals that OsNPR1/NH1 is the rice orthologue conferring disease resistance with enhanced herbivore susceptibility. Plant Biotechnology Journal 5:313-24.

Zhang, S. and Liu, Y. (2001) Activation of salicylic acidinduced protein kinase, a mitogen-activated protein kinase, induces multiple defence responses in tobacco. Plant Cell 13, 1877-1889.

Zhonghua $\mathrm{Ma}^{1}$, Themis J. Michailides (2005), Advances in understanding molecular mechanisms of fungicide resistance and molecular detection of resistant genotypes in phytopathogenic fungi. Crop Protection 24:853-863.

Zhao BY, Lin XH, Poland J, Trick H, Leach J, Hulbert S. (2005) A maize resistance gene functions against bacterial streak disease in rice. Proceedings of the National Academy of Sciences USA 102:15383-8.

Zhao LY, Chen JL, Cheng DF, Sun JR, Liu Y, Tian Z. (2009) Biochemical and molecular characterizations of Sitobion avenaeinduced wheat defence responses. Crop Protection 28:435-42; http://dx.doi. org/10.1016/j.cropro.2009.01.005.

Zhu Q, Maher EA, Masoud S, Dixon RA, Lamb CJ. (1994) Enhanced protection against fungal attack by constitutive coexpression of chitinase and glucanase genes in transgenic tobacco. Nature Biotechnol 1994; 12:807-12.c 